\title{
Influence of Pooled Colostrum or Colostrum Replacement on IgG and Evaluation of Animal Plasma in Milk Replacer
}

\author{
C. M. Jones, ${ }^{1}$ R. E. James, ${ }^{1}$ J. D. Quigley, III, ${ }^{2}$ and M. L. McGilliard ${ }^{1}$ \\ ${ }^{1}$ Virginia Polytechnic Institute and State University, Blacksburg 24061 \\ ${ }^{2}$ APC, Inc., Ankeny, IA 50021
}

\begin{abstract}
Newborn Holstein $(\mathrm{n}=48)$ and Jersey $(\mathrm{n}=30)$ calves were studied to compare absorption of immunoglobulin $\mathrm{G}(\mathrm{IgG})$ from maternal colostrum $(\mathrm{n}=39)$ or colostrum replacement containing an Ig concentrate derived from bovine serum $(\mathrm{n}=39)$. Calves were also fed milk replacer with $(n=38)$ or without $(n=40)$ animal plasma (20\% of crude protein) to $29 \mathrm{~d}$ of age to determine effect of plasma protein on IgG status, health, and growth. Calves were fed maternal colostrum or colostrum replacement at 1.5 and $13.5 \mathrm{~h}$ of age and provided a total of 250 or 249 and 180 or $186 \mathrm{~g}$ of IgG for Holsteins and Jerseys fed maternal colostrum or colostrum replacement, respectively. Milk replacer $(12.5 \% \mathrm{DM})$ was fed at $31 \%$ of metabolic birth weight ( 2 feedings/d). Plasma was sampled at $0 \mathrm{~h}, 24 \mathrm{~h}$, and weekly to determine IgG by turbidimetric immunoassay. At blood collection, calves were weighed and measured to determine growth. Health scores, fecal scores, and grain intake were measured daily. Plasma IgG at $24 \mathrm{~h}$ did not differ between calves fed maternal colostrum $(13.78 \pm 0.39 \mathrm{~g} /$ $\mathrm{L})$ and colostrum replacement $(13.96 \pm 0.38 \mathrm{~g} / \mathrm{L})$. Average daily gain, withers height, hip height, body length, heart girth, health, and incidence of diarrhea were not different between treatment groups. Calves fed maternal colostrum used feed more efficiently than calves fed colostrum replacement. Plasma IgG and performance were not affected by the addition of animal plasma to milk replacer. The colostrum replacement used in this study provided adequate IgG for newborn calves. Animal plasma was an acceptable source of protein but did not enhance growth or immunity under the conditions of this study.
\end{abstract}

(Key words: IgG, colostrum replacement, animal plasma, calf milk replacer)

Abbreviation key: AEA = apparent efficiency of absorption, $\mathbf{C R}=$ colostrum replacer, $\mathbf{F P T}=$ failure of

Received September 12, 2003.

Accepted December 17, 2003.

Corresponding author: R. E. James; e-mail: jamesre@vt.edu. passive transfer, $\mathbf{M C}=$ maternal colostrum, $\mathbf{P U N}=$ plasma urea nitrogen, $\mathbf{C M R}=$ calf milk replacer.

\section{INTRODUCTION}

Timely, adequate colostrum intake is the most important management factor affecting morbidity and mortality in preweaned calves (Wells et al., 1996). Absorption of intact immunoglobulins begins to decline immediately after birth and ends completely by about $24 \mathrm{~h}$ (Stott et al., 1979). Inadequate absorption of colostral immunoglobulins, or failure of passive transfer (FPT), is common and increases morbidity and mortality risk (NAHMS, 1993). Many diseases, including Johne's, can be passed to calves via maternal colostrum (MC), and producers are advised to discard or pasteurize MC from infected cows (Stabel, 2001). This practice can reduce the supply of available MC and may force producers to use colostrum containing less IgG.

Colostrum supplement products, which typically contain 25 to $45 \mathrm{~g} / \mathrm{L} \mathrm{IgG}$, can be added to $\mathrm{MC}$ to increase IgG mass (Davenport et al., 2000). Supplements made from dried colostrum (Zaremba et al., 1993) or dried whey (Garry et al., 1996; Mee et al., 1996) did not improve absorption of IgG over MC. Supplements based on purified blood proteins have improved IgG absorption in some reports (Todd et al., 1993; Arthington et al., 2000b), but not in other reports (Arthington et al., 2000a; Quigley et al., 2000a). Supplementation does not eliminate $\mathrm{MC}$ as a disease transmission vehicle; however, replacement of MC may be able to prevent disease. Quigley et al. (1998b, 2002) reported colostrum replacer (CR) products provided adequate IgG to calves. Any CR must contain sufficient absorbable IgG to effectively mimic colostrum in establishing passive immunity. Although immunoglobulins contained in CR may not provide protection to farm-specific pathogens, CR have potential advantages in consistent composition and quality. An effective CR would provide a viable alternative for producers facing limited or contaminated colostrum supplies.

Blood proteins also have potential as milk replacer protein sources (Morrill et al., 1995; Quigley and Bernard, 1996). Spray-dried plasma protein is soluble, has 
Table 1. Number of calves in each treatment, breed, and gender group.

\begin{tabular}{llll}
\hline & \multicolumn{2}{c}{ Milk replacer } & \\
\cline { 2 - 3 } & No plasma & Plasma & Total \\
\hline IgG source & & & \\
Maternal colostrum & 20 & 19 & 39 \\
Colostrum replacement & 20 & 19 & 39 \\
Total & 40 & 38 & 78 \\
Breed-gender & Female & Male & Total \\
Holstein & 23 & 25 & 48 \\
Jersey & 11 & 19 & 30 \\
Total & 34 & 44 & 78 \\
\hline
\end{tabular}

an AA profile similar to skim milk, and was used at 95\% of casein utilization in rats (Duarte et al., 1999). Plasma proteins may provide immunoglobulins that could exert local protection in the intestine and improve animal health and performance (Drew, 1994). Since IgG absorbed from MC is largely returned to the gastrointestinal tract (Besser et al., 1988), it is possible plasma IgG could reduce clearance of IgG from blood.

The objectives of the present study were to compare 24-h IgG concentrations in calves fed pooled MC or CR (Acquire, APC, Inc., Ankeny, IA) and to compare plasma IgG status and apparent IgG clearance rate in calves fed calf milk replacer (CMR) with or without animal plasma.

\section{MATERIALS AND METHODS}

\section{Animal and Feeding Practices}

Calves from the Virginia Tech Dairy Cattle Center were blocked by gender and breed and were assigned to each block independently. Seventy-eight calves born between June 5 and December 3, 2000, were assigned to one of 4 treatments: $\mathrm{CR}+$ milk replacer with animal plasma contributing $20 \%$ of CP, CR + milk replacer without animal plasma, $\mathrm{MC}+$ milk replacer with animal plasma, $\mathrm{MC}+$ milk replacer without animal plasma (control). Table 1 describes treatment, breed, and gender groups.

Calvings were supervised, and any calf whose birth was not observed was not included. Within $15 \mathrm{~min}$ of birth, calves were moved to a calf facility, identified, and weighed. They were vaccinated for bovine rhinotracheitis, parainfluenza 3 (Pfizer, Exton, PA), rotavirus, and corona virus (Pfizer) injected with vitamins A, D, and E (Phoenix Pharmaceuticals, St. Joseph, MO) and selenium (Schering Plough, Kenilworth, NJ), and navels were dipped with $7 \%$ iodine tincture. At birth, 24 $\mathrm{h}$, and weekly for $4 \mathrm{wk}$, BW, withers height, hip height, body length (point of shoulder to caudal projection of pin bone), and heart girth were measured. Calves were housed individually in $1.22-\times 1.83-\mathrm{m}$ stalls.

Calves were fed CR or pooled MC within $1.5 \mathrm{~h}$ of birth and $12 \mathrm{~h}$ later. All calves were fed by nipple bottle, although an esophageal feeder was used when calves refused to suckle. Amounts of MC and CR were adjusted to provide IgG equal to a standard dose of CR $(9.83 \mathrm{~g}$ of IgG/ $/ \mathrm{kg}$ of metabolic BW). Using average BW of calves at the Virginia Tech Dairy Cattle Center, it was determined that Jerseys should be fed $75 \%$ of standard dose.

Maternal colostrum was collected, pooled, and refrozen into aliquots prior to the start of the study. First and second milking MC that registered green on a colostrometer (Biogenics, Mapleton, OR) was pooled. Samples of MC were collected for IgG analysis prior to freezing. Amounts of MC fed were adjusted based on IgG concentration, as determined by radial immunodiffusion (Triple J Farms, Redmond, WA). Holstein and Jersey calves fed MC received 1.42 and $1.06 \mathrm{~L}$ at each feeding. Holstein and Jersey calves fed CR received 454 and $340.5 \mathrm{~g}$ of powder dissolved in 1.89 and $1.42 \mathrm{~L}$ of water $\left(38^{\circ} \mathrm{C}\right)$. The $\mathrm{CR}$ was manufactured as described by Quigley et al. (2001). Nutrient composition of feeds is in Table 2.

Calves were fed CMR with or without animal plasma from nipple pails twice daily at 0800 and $1630 \mathrm{~h}$ beginning $24 \mathrm{~h}$ after birth. The CMR was reconstituted to $12.5 \% \mathrm{DM}$ and fed at $31 \%$ of metabolic birth weight for $29 \mathrm{~d}$. To determine feeding rate, energy requirement of calves gaining $227 \mathrm{~g} / \mathrm{d}$, and energy content of average milk replacer were calculated (Davis and Drackley, 1998).

Beginning on d 1, calves were offered $250 \mathrm{~g} / \mathrm{d}$ starter grain containing decoquinate (Deccox, Alpharma, Fort Lee, NJ). Starter intake was measured daily by weighing refusals. Starter was increased by $50 \mathrm{~g}$ if daily orts were less than $25 \mathrm{~g}$. Water was available free choice beginning 1 to $2 \mathrm{~d}$ after birth.

\section{Sampling and Laboratory Methods}

Prefeeding blood samples were drawn at $1 \mathrm{~h}(0 \mathrm{~d})$, $24 \mathrm{~h}(1 \mathrm{~d}), 8 \mathrm{~d}, 15 \mathrm{~d}, 22 \mathrm{~d}$, and $29 \mathrm{~d}$. Packed cell volume was measured at 1 and $24 \mathrm{~h}$ to estimate changes in plasma volume. Blood samples were collected by jugular venipuncture into evacuated glass tubes containing potassium EDTA. Blood was immediately centrifuged at $1745 \times g\left(15 \mathrm{~m}\right.$ at $\left.4^{\circ} \mathrm{C}\right)$ and stored at $-20^{\circ} \mathrm{C}$. At the end of the trial, one plasma aliquot was sent to APC, Inc. for IgG (Etzel et al., 1997) and total protein analyses (Smith et al., 1985). Remaining plasma aliquot was analyzed at Virginia Tech for urea N (Chaney and Marbach, 1962; Weatherburn, 1967). 
Table 2. Nutrient composition of feeds on a DM basis.

\begin{tabular}{|c|c|c|c|c|c|}
\hline \multirow[b]{2}{*}{ Item } & \multirow[b]{2}{*}{ Colostrum $^{1}$} & \multirow{2}{*}{$\begin{array}{l}\text { Colostrum } \\
\text { replacement }\end{array}$} & \multicolumn{2}{|c|}{ Milk replacer } & \multirow{2}{*}{$\begin{array}{l}\text { Starter } \\
\text { grain }\end{array}$} \\
\hline & & & No plasma & Plasma & \\
\hline $\mathrm{DM}(\%)$ & 24.0 & 96.02 & 96.81 & 97.3 & 88.88 \\
\hline $\mathrm{CP}(\%)$ & 58.3 & 44.35 & 22.02 & 22.81 & 20.44 \\
\hline Milk protein (\% of CP) & $\ldots$ & $\ldots$ & 100 & 80 & $\ldots$ \\
\hline Plasma protein (\% of $\mathrm{CP})$ & $\ldots$ & $\ldots$ & 0 & 20 & $\ldots$ \\
\hline Fat $(\%)$ & 27.9 & 3.44 & 21.27 & 21.08 & 4.67 \\
\hline Ash $(\%)$ & 4.63 & 4.69 & 7.46 & 8.59 & 6.09 \\
\hline $\mathrm{ADF}(\%)$ & & $\ldots$ & & & 4.74 \\
\hline $\mathrm{Ca}(\mathrm{mg} / 100 \mathrm{~g})$ & 1083.3 & 373 & 1090 & 1510 & 1020 \\
\hline $\mathrm{P}(\mathrm{mg} / 100 \mathrm{~g})$ & & 619 & 983 & 1240 & 709 \\
\hline $\mathrm{K}(\mathrm{mg} / 100 \mathrm{~g})$ & 583.3 & 142 & 1210 & 1170 & 999 \\
\hline $\mathrm{Mg}(\mathrm{mg} / 100 \mathrm{~g})$ & 166.7 & 80.6 & 130 & 178 & 213 \\
\hline
\end{tabular}

${ }^{1}$ Colostrum nutrient composition was not analyzed; average values (Foley and Otterby, 1978) are reported for comparison only.

Calves were monitored during each feeding, and health problems and treatments were recorded. Fecal scores were evaluated once daily using a 3-point scale $(0=$ firm, 1 = loose, and 2 = watery). Clinical health was scored based on ability to stand and presence or absence of suckle reflex. The score had a maximum of 2 points, 1 for each category (does not stand $=0$, stands $=$ 1 plus suckle reflex absent $=0$, suckle reflex present $=1$ ).

\section{Statistical Analysis}

Data were analyzed as a split-plot design with repeated measures on the subplot (time) using SAS mixed procedure (Littell et al., 1996). The model was:

$$
\begin{gathered}
\mathrm{Y}_{\mathrm{ijklmno}}=\mu+\mathrm{S}_{\mathrm{i}}+\mathrm{M}_{\mathrm{j}}+\mathrm{SM}_{\mathrm{ij}}+\mathrm{B}_{\mathrm{k}}+\mathrm{G}_{\mathrm{l}}+\mathrm{BG}_{\mathrm{kl}}+\mathrm{SB}_{\mathrm{ik}} \\
+\mathrm{SG}_{\mathrm{il}}+\mathrm{MB}_{\mathrm{jk}}+\mathrm{MG}_{\mathrm{jl}}+\mathrm{SMB}_{\mathrm{ijk}}+\mathrm{SMG}_{\mathrm{ijl}}+\mathrm{SBG}_{\mathrm{ikl}} \\
+\mathrm{MBG}_{\mathrm{jkl}}+\mathrm{SMBG}_{\mathrm{ijkl}}+\mathrm{R}_{\mathrm{m}}+\mathrm{SMBGR}_{\mathrm{ijklm}} \\
+\mathrm{A}\left(\mathrm{SMBGR}_{\mathrm{ijklm}) \mathrm{n}}+\mathrm{T}_{\mathrm{o}}+\mathrm{ST}_{\mathrm{io}}+\mathrm{MT}_{\mathrm{jo}}+\mathrm{SMT}_{\mathrm{ijo}}+\mathrm{BT}_{\mathrm{ko}}\right. \\
+\mathrm{GT}_{\mathrm{lo}}+\mathrm{BGT}_{\mathrm{klo}}+\mathrm{SBT}_{\mathrm{iko}}+\mathrm{SGT}_{\mathrm{ilo}}+\mathrm{MBT}_{\mathrm{jko}}+\mathrm{MGT}_{\mathrm{jlo}} \\
+\varepsilon_{\mathrm{ijklmno}}
\end{gathered}
$$

where:

$\mathrm{S}=$ source of $\mathrm{IgG}$, colostrum or replacement $(\mathrm{i}=1,2)$; fixed effect

$\mathrm{M}=$ milk replacer, no plasma or plasma $(\mathrm{j}=1$, 2); fixed effect

$\mathrm{B}=$ breed, Holstein or Jersey $(\mathrm{k}=1,2)$; fixed effect

$\mathrm{G}=$ gender, female or male $(1=1,2)$; fixed effect

$\mathrm{R}=$ replication, colostrum pool $(\mathrm{m}=1,2)$; random effect

$\mathrm{A}=$ calf $(\mathrm{n}=1 \ldots 20) ;($ total of 78 calves $)$ random effect
$\mathrm{T}=$ time, $\mathrm{d}$ or $\mathrm{wk}$, depending on variable tested, if $\mathrm{d}(\mathrm{o}=1,8,15,22,29)$, if wk (o = $1 \ldots 4)$, fixed effect

$\varepsilon=$ residual

Replication and calf were random; all other effects were fixed. Tests of effect of IgG source, milk replacer, breed, gender, and replication were conducted using calf within the interaction of source by replacer, breed, gender, and replication as the error term. Significance was declared at $P<0.05$. When interactions of main effects were significant, the slice option was used to clarify which effects were significant. When the variable tested was an overall change, effect of time (day or week) was removed from the model. Health and fecal scores were tested by performing $\chi^{2}$ tests in SAS using the frequency procedure.

\section{RESULTS AND DISCUSSION}

\section{Plasma IgG at $24 \mathrm{~h}$}

Differences in birth BW or age at first feeding were not detected (Table 3). Plasma IgG was undetectable in all 0-h samples, which verified calves did not nurse their dams. Plasma IgG increased to $13.76 \pm 0.66 \mathrm{~g} / \mathrm{L}$ in MC-fed calves and $13.84 \pm 0.65 \mathrm{~g} / \mathrm{L}$ in CR-fed calves at $24 \mathrm{~h}$. Differences were not detected between treatments in 24-h IgG or apparent efficiency of absorption (AEA). The AEA was $19.2 \pm 0.8$ and $20.3 \pm 0.8 \%$ for MC- and CR-fed calves (Table 4).

Calves fed CR had greater plasma IgG concentrations at $24 \mathrm{~h}$ than previously reported $(5.0$ to $8.3 \mathrm{~g} / \mathrm{L})$ for bovine serum-based products (Arthington et al., 2000a, 2000b; Quigley et al., 2000a). In previous research, CR provided $90 \mathrm{~g}$ of $\mathrm{IgG}$. In the present experiment, calves received 250 (Holsteins) or 180 (Jerseys) g of IgG. The 
Table 3. Least square means of calf birth weight, age at feedings, and Ig intake.

\begin{tabular}{|c|c|c|c|c|c|}
\hline \multirow[b]{3}{*}{ Variable } & \multicolumn{4}{|c|}{ Least square means } & \multirow[b]{3}{*}{$\mathrm{SE}$} \\
\hline & \multicolumn{4}{|c|}{ Treatment $^{1}$} & \\
\hline & $\mathrm{CN}$ & CPL & $\mathrm{RN}$ & RPL & \\
\hline Calves, initial number & 20 & 19 & 20 & 19 & $\ldots$ \\
\hline Calves, final number & 19 & 16 & 20 & 19 & \\
\hline Birth weight $(\mathrm{kg})$ & 34.0 & 35.5 & 35.9 & 36.4 & 2.0 \\
\hline \multicolumn{6}{|l|}{ Age at feeding (h) } \\
\hline First feeding & 1.2 & 1.1 & 1.0 & 0.9 & 0.2 \\
\hline Second feeding & 13.2 & 13.1 & 13.0 & 12.9 & 0.2 \\
\hline \multicolumn{6}{|l|}{ IgG intake (g) } \\
\hline Holsteins & 250.6 & 250.6 & 250.0 & 250.0 & $\ldots$ \\
\hline Jerseys & 182.5 & 180.2 & 180.0 & 180.0 & \\
\hline
\end{tabular}

${ }^{1} \mathrm{CN}=$ Pooled maternal colostrum at birth, no plasma in milk replacer; $\mathrm{CPL}=$ Pooled maternal colostrum at birth, plasma in milk replacer; $\mathrm{RN}=$ colostrum replacement at birth, no plasma in milk replacer; RPL = colostrum replacement at birth, plasma in milk replacer.

IgG concentrations were similar to those reported in calves fed the same dose of this CR (Quigley et al., 2002). The AEA was in the low end of the range of previously reported values for MC (30 to $35 \%)$ and CR (30\%) (Quigley et al., 2002), but similar to a recent experiment conducted at Virginia Tech using an earlier formulation of the same product (Quigley et al., 2000a). There was concern that volume of fluid may have been confounded with treatment as calves fed CR received a greater volume of liquid than those receiving MC. However, the mass of IgG fed was similar regardless of treatment, and Stott and Fellah (1983) found that mass of IgG fed was more important than concentration of IgG fed.

Jersey calves had higher 24-h IgG concentrations than Holsteins (16.47 \pm 0.71 and $11.12 \pm 0.60 \mathrm{~g} / \mathrm{L})$, and absorbed IgG with $21.9 \pm 0.9 \%$ efficiency compared with
$17.0 \pm 0.7 \%$ for Holsteins (Table 5). Jersey calves maintained greater plasma IgG concentrations than Holsteins from d 1 through d 15.

No differences in IgG concentration or AEA were found between male and female Jerseys, but Holstein males absorbed IgG more efficiently and attained higher IgG concentrations at $24 \mathrm{~h}$ than females (Table 5). Breed differences in IgG absorption have been reported previously and may result from differences in body size and plasma volume (Quigley et al., 1998a).

Plasma IgG concentrations less than $10 \mathrm{~g} / \mathrm{L}$ were observed in 15 calves (19.2\%), and 24-h IgG concentrations ranged from 0.01 to $21.09 \mathrm{~g} / \mathrm{L}$ (Table 6). Percentage of calves with FPT was within the range of normally observed values but is high given tightly controlled experimental conditions. Average age of calves at first feeding was $1.05 \mathrm{~h}$, and only 5 calves were more than

Table 4. Least square means of plasma protein, IgG, and urea nitrogen (PUN) in calves fed pooled maternal colostrum (C) or replacement (R) and milk replacer with (PL) or without $(\mathrm{N})$ animal plasma at birth and $24 \mathrm{~h}$.

\begin{tabular}{|c|c|c|c|c|c|c|c|c|c|}
\hline \multirow[b]{3}{*}{ Variable } & \multicolumn{4}{|c|}{ Least square means } & \multirow[b]{3}{*}{ SE } & \multicolumn{4}{|c|}{ Differences of means ${ }^{1}$} \\
\hline & \multicolumn{2}{|c|}{ Colostrum } & \multicolumn{2}{|c|}{ Replacement } & & \multicolumn{2}{|c|}{$\mathrm{N}$ minus $\mathrm{PL}$} & \multicolumn{2}{|c|}{ MC minus $\mathrm{R}$} \\
\hline & $\mathrm{N}$ & PL & $\mathrm{N}$ & PL & & $\mathrm{MC}$ & $\mathrm{R}$ & $\mathrm{N}$ & $\mathrm{P}$ \\
\hline 0-h IgG (g/L) & 0.00 & 0.00 & 0.00 & 0.00 & 0.00 & 0.00 & 0.00 & 0.00 & 0.00 \\
\hline 24-h IgG (g/L) & 13.74 & 13.77 & 14.05 & 13.63 & 0.74 & -0.03 & 0.42 & -0.31 & 0.15 \\
\hline AEA of $\operatorname{IgG}^{2}(\%)$ & 18.73 & 19.65 & 20.28 & 20.35 & 0.89 & -0.92 & -0.06 & -1.55 & -0.69 \\
\hline $0-\mathrm{h}$ Total protein $(\mathrm{g} / \mathrm{dl})$ & 4.312 & 4.323 & 4.107 & 4.282 & 0.105 & -0.012 & -0.175 & 0.205 & 0.042 \\
\hline 24-h Total protein $(\mathrm{g} / \mathrm{dl})$ & 6.063 & 5.946 & 5.416 & 5.505 & 0.128 & 0.116 & -0.088 & $0.646^{* *}$ & $0.442^{* *}$ \\
\hline 0 -h PUN (mg/dl) & 13.858 & 14.569 & 15.329 & 15.776 & 0.842 & -0.711 & -0.446 & -1.471 & -1.206 \\
\hline 24-h PUN (mg/dl) & 12.291 & 12.900 & 10.214 & 9.840 & 0.756 & -0.609 & 0.374 & $2.077^{*}$ & $3.060 * *$ \\
\hline
\end{tabular}

${ }^{1}$ Significance determined by slicing interaction of IgG source and milk replacer.

${ }^{2}$ Apparent efficiency of absorption: (plasma IgG at $24 \mathrm{~h} \times \mathrm{BW}$ at birth, $\left.\mathrm{kg} \times 0.091\right) / \mathrm{IgG}$ intake $(\mathrm{g})$.

$* P<0.05$.

$* * P<0.01$. 
Table 5. Least square means of plasma protein, IgG, and urea nitrogen (PUN) in Holstein (H) and Jersey (J), male (M) and female (F) calves at birth and $24 \mathrm{~h}$ of age.

\begin{tabular}{|c|c|c|c|c|c|c|c|c|c|}
\hline \multirow[b]{3}{*}{ Variable } & \multicolumn{4}{|c|}{ Least square means } & \multirow[b]{3}{*}{ SE } & \multicolumn{4}{|c|}{ Differences of means ${ }^{1}$} \\
\hline & \multicolumn{2}{|c|}{ Holstein } & \multicolumn{2}{|c|}{ Jersey } & & \multicolumn{2}{|c|}{$\mathrm{F}$ minus $\mathrm{M}$} & \multicolumn{2}{|c|}{$\mathrm{H}$ minus $\mathrm{J}$} \\
\hline & $\mathrm{F}$ & M & $\mathrm{F}$ & M & & $\mathrm{H}$ & $\mathrm{J}$ & $\mathrm{F}$ & M \\
\hline 0-h IgG (g/L) & 0.00 & 0.00 & 0.00 & 0.00 & 0.00 & 0.00 & 0.00 & 0.00 & 0.00 \\
\hline 24-h IgG (g/L) & 9.90 & 12.35 & 16.75 & 16.19 & 0.92 & $-2.44^{*}$ & 0.56 & $-6.85^{* *}$ & $-3.84 * *$ \\
\hline AEA of $\operatorname{IgG}^{2}(\%)$ & 15.48 & 19.74 & 21.54 & 22.25 & 1.10 & $-4.27 * *$ & -0.71 & $-6.07 * *$ & $-2.51 \dagger$ \\
\hline 0 -h Total protein $(\mathrm{g} / \mathrm{dL})$ & 4.284 & 4.440 & 4.196 & 4.104 & 0.130 & -0.155 & 0.091 & 0.089 & $0.335^{*}$ \\
\hline 24-h PUN (mg/dL) & 9.902 & 10.408 & 12.526 & 12.408 & 0.940 & -0.506 & 0.118 & $-2.624^{*}$ & $-2.000 *$ \\
\hline
\end{tabular}

${ }^{1}$ Significance determined by slicing interaction of breed and gender.

${ }^{2}$ Apparent efficiency of absorption: (plasma IgG at $24 \mathrm{~h} \times \mathrm{BW}$ at birth, $\left.\mathrm{kg} \times 0.091\right) / \mathrm{IgG}$ intake $(\mathrm{g})$.

$\dagger P<0.10$.

$* P<0.05$.

$* * P<0.01$.

2-h-old at first feeding. All calves received MC or CR containing greater than $66 \mathrm{~g} / \mathrm{L} \mathrm{IgG}$. Calves were fed following best management practices, yet still experienced a high rate of FPT. Reasons for the high frequency of FPT in female Holstein calves were not apparent, as all calves were treated similarly during the trial.

\section{Apparent Clearance of IgG}

Concentrations of $\mathrm{IgG}$ declined in a quadratic manner from $\mathrm{d} 1$ to 29. IgG concentrations in calves fed CR were higher than in MC-fed calves on d 8 and 15 (Figure 1). Differences in IgG concentrations between calves fed plasma in CMR and calves fed control CMR were not detected. To estimate clearance rate, change in IgG from day $\times$ to day y was divided by IgG on $d x$ (e.g., [(d $1-\mathrm{d} 8) / \mathrm{d} 1] \times 100)$. Apparent clearance rates were calculated for each 7-d period (Figure 2). Calves fed MC had an apparent clearance rate of $3.5 \%$ per day in wk 1 , which agrees well with estimates determined by

Table 6. Failure of passive transfer incidence (percent) as determined by plasma IgG concentration at $24 \mathrm{~h}$.

\begin{tabular}{lllcc}
\hline & & & \multicolumn{2}{c}{ Range of IgG $(\mathrm{g} / \mathrm{L})$} \\
\cline { 3 - 5 } & $\mathrm{n}$ & $<10 \mathrm{~g} / \mathrm{L}$ & $\min$ & $\max$ \\
\hline Overall & 78 & 19.2 & 0.01 & 21.09 \\
$\begin{array}{l}\text { Treatment } \\
\quad \text { Colostrum }\end{array}$ & 39 & 20.5 & 6.80 & 19.95 \\
$\quad \begin{array}{l}\text { Replacement } \\
\text { Breed }\end{array}$ & 39 & 17.9 & 0.01 & 21.09 \\
$\quad$ Jersey & 30 & 0.0 & 10.80 & 21.09 \\
$\quad$ Holstein & 48 & 31.3 & 0.01 & 17.85 \\
Gender & & & & \\
$\quad$ Male & 44 & 11.4 & 7.95 & 20.39 \\
$\quad$ Female & 34 & 29.4 & 0.01 & 21.09 \\
\hline
\end{tabular}

clearance of ${ }^{125}$ I-labeled IgG $_{1}$ (Besser et al., 1988). Rate of clearance in wk $2(1.98 \%)$ was also similar to calculations of Besser et al. (1988). Based on these estimates, calves either cleared less IgG or produced more IgG as age increased. Since endogenous IgG production can begin at $3 \mathrm{~d}$ (Devery et al., 1979), it is likely that endogenous production increased with age, resulting in an apparent decrease in clearance rate in wk 3 and a gain in IgG over wk 4.

These estimates are probably appropriate for calves fed MC, but may not apply to calves fed CR. Ratio of $\mathrm{IgG}_{1}$ to $\mathrm{IgG}_{2}$ in serum is approximately $1: 1$ (Mayer et al., 2002), but in colostrum it is skewed toward $\operatorname{IgG}_{1}$ at

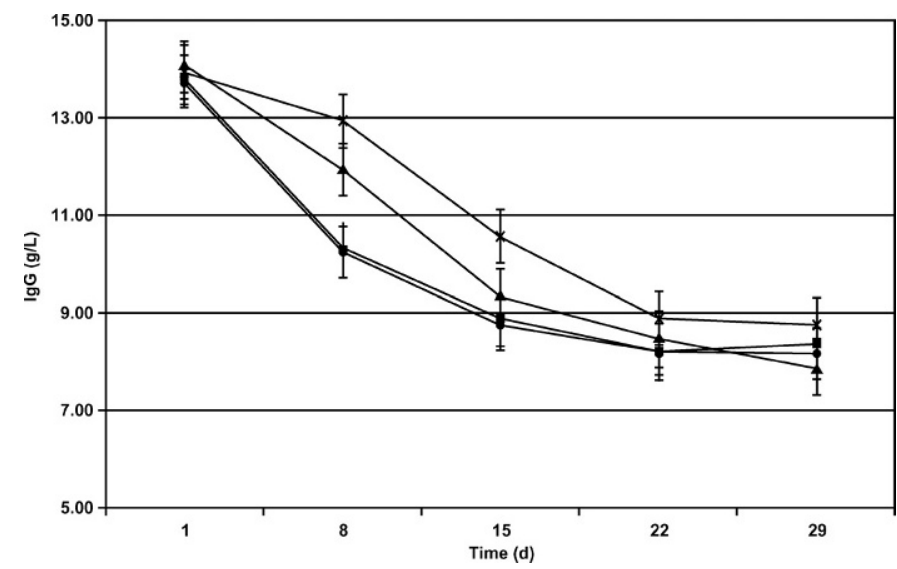

Figure 1. Plasma IgG concentrations (g/L) on d 1 to $d 29$ in calves fed maternal colostrum at birth and milk replacer without animal plasma for $1 \mathrm{mo}(\mathbf{)})$, maternal colostrum at birth and milk replacer with animal plasma for 1 mo ( $\mathbf{\square})$, colostrum replacement at birth and milk replacer without animal plasma for $1 \mathrm{mo}(\mathbf{\Delta})$, or colostrum replacement at birth and milk replacer with animal plasma for 1 mo $(\times)$. Significant source $\times$ time interaction; differences detected $d 8$ and 15. Significant linear and quadratic contrasts detected. 


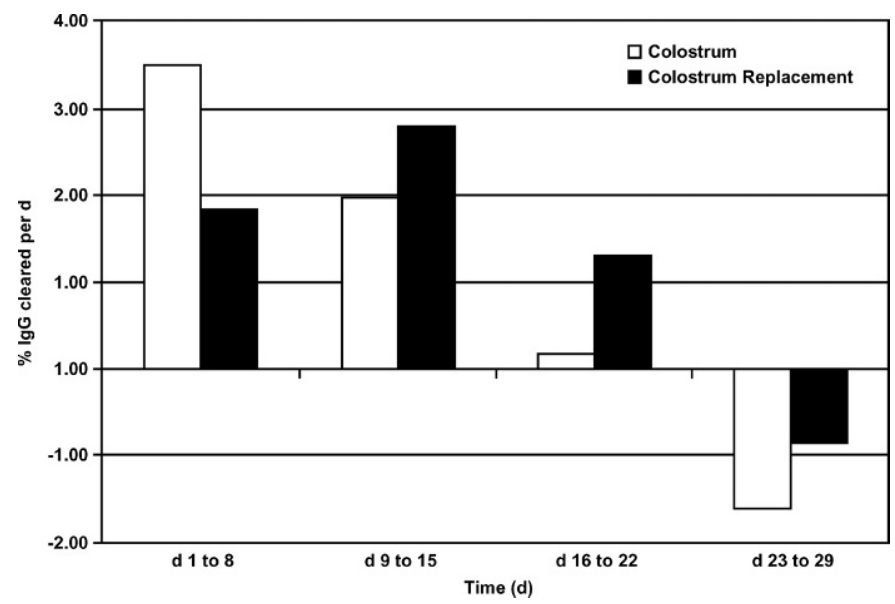

Figure 2. Calculated estimates of apparent plasma IgG clearance rates (\% of total plasma IgG cleared daily) from d 1 to 29 of age in calves fed colostrum (open bars) or colostrum replacement (solid bars).

95:5 (Butler, 1983). In calves fed serum-derived CR, half of the passively acquired IgG was likely $\operatorname{IgG}_{2}$, and clearance of IgG acquired from CR may follow a different pattern. Calves fed CR appeared to clear IgG less rapidly. This may be explained by Mayer et al. (2002), who found that the $\mathrm{Fc}$ receptor in the neonate is specific for $\mathrm{IgG}_{1}$ and is responsible for resecretion of circulating IgG back into the lumen of the intestine. It would follow that if there were more $\operatorname{IgG}_{1}$ in the blood of calves receiving $\mathrm{MC}$ it would be cleared from the blood more rapidly, resulting in lower IgG levels in the calf with increasing age. Alternatively, increased endogenous IgG production may have occurred. Previous work has shown that hypogammaglobulinemic calves begin synthesizing IgG earlier than calves with adequate IgG (Logan et al., 1974).

\section{Growth, Feed Efficiency, and Health}

Body weights were not different between treatment groups at birth (Table 3 ) and from d 8 through 29. Body weight on d 1 was greater in CR calves; however, CR calves received more liquid in the first $24 \mathrm{~h}$ than $\mathrm{MC}$ calves due to the high IgG content of MC. Based on the assumption that added weight was fluid, not true body mass increase; $d 1$ weights were replaced with $d 0$ weights for contrast tests and calculations of average daily gain. Body weight increased quadratically with age.

From d 0 to 8, calves fed CR tended to gain less BW than calves fed $\mathrm{MC}(P<0.06 ;-120.7 \pm 7.8$ and $51.6 \pm$ $7.8 \mathrm{~g} / \mathrm{d}$ ). By d 15, differences between treatments were undetectable. Overall BW gain, average daily gain, withers height, hip height, body length, and heart girth did not differ by treatment. Calves fed CMR containing animal plasma grew at the same rate as calves fed control CMR. Other researchers feeding animal plasma reported similar results; however, gains in the current experiment were lower than those reported previously (Morrill et al., 1995; Quigley and Bernard, 1996). Growth measurements by breed and gender are in Table 7 .

Starter intake increased in a linear and quadratic manner from $\mathrm{d} 1$ to 29 , and no differences were detected between treatments (Table 8 ). Calves fed MC were more feed efficient than CR-fed calves overall (0.394 \pm 0.082 vs. $0.241 \pm 0.083 \mathrm{~kg}$ of gain $/ \mathrm{kg}$ of DMI). However, when gains were analyzed by week, calves fed MC were more feed efficient only in wk 1 (Figure 3). Holsteins converted feed into BW gain more efficiently than Jerseys $(0.391 \pm 0.081$ compared with $0.244 \pm 0.084 \mathrm{~kg}$ of gain/ $\mathrm{kg}$ of DMI). Observed feed efficiencies fall within the range of values $(0.330$ to $0.680 \mathrm{~kg}$ of gain $/ \mathrm{kg}$ of DMI) reported by other researchers (Lammers et al., 1998; Quigley et al., 2000b).

\section{Plasma Urea Nitrogen}

No differences in plasma urea nitrogen (PUN) were found between treatment groups at birth or from $d 8$ to 29; however, calves fed MC had higher concentrations of PUN on $d 1$ than calves fed CR $(12.60 \pm 0.78$ and 10.03 $\pm 0.77 \mathrm{mg} / \mathrm{dL}$ ). Calves fed $\mathrm{CR}$ received a greater volume of liquid in the first $24 \mathrm{~h}$ and probably receive less protein than calves fed MC. Colostrum was not analyzed for protein, but contains about $15 \%$ protein (Foley and Otterby, 1978) as compared with the CR used in this study, which contained about $10 \%$ protein. Calves fed CR appeared to experience a greater increase in plasma volume as evidenced by reduced packed cell volume from d 0 to 1 than MC-fed calves; packed cell volume decreased by $4.39 \pm 0.75$ and $2.63 \pm 0.76$ percentage points from d 0 to 1 for CR and MC-fed calves, respectively. Therefore, PUN concentrations may be diluted in CR calves on $\mathrm{d} 1$.

From d 1 to 22, Jerseys had higher PUN concentrations than Holsteins. Jersey calves fed CR experienced greater plasma volume expansion than Holstein calves fed CR $(5.72 \pm 0.97 \%$ and $3.07 \pm 0.82 \%)$, but Jerseys have lower plasma volume than Holsteins (Quigley et al., 1998a). Jersey calves had greater total plasma protein than Holstein calves on d 1, 8, and 22, which could also occur due to lower plasma volume. Alternatively, greater total plasma protein, as a result of greater absorption of protein from initial feedings of MC or CR, could lead to increased PUN concentrations as the excess protein is metabolized and cleared from the body. 
Table 7. Least square means of growth and intake parameters in Holstein $(\mathrm{H})$ and Jersey $(\mathrm{J})$, male $(\mathrm{M})$ and female (F) calves.

\begin{tabular}{|c|c|c|c|c|c|c|c|c|c|}
\hline \multirow[b]{3}{*}{ Variable } & \multicolumn{4}{|c|}{ Least square means } & \multirow[b]{3}{*}{ SE } & \multicolumn{4}{|c|}{ Differences of means ${ }^{1}$} \\
\hline & \multicolumn{2}{|c|}{ Holstein } & \multicolumn{2}{|c|}{ Jersey } & & \multicolumn{2}{|c|}{$\mathrm{F}$ minus $\mathrm{M}$} & \multicolumn{2}{|c|}{$\mathrm{H}$ minus $\mathrm{J}$} \\
\hline & $\mathrm{F}$ & M & $\mathrm{F}$ & $\mathrm{M}$ & & $\mathrm{H}$ & $\mathrm{J}$ & $\mathrm{F}$ & M \\
\hline BW gain d $0-29(\mathrm{~kg})$ & 6.420 & 8.591 & 3.789 & 2.045 & 1.429 & $-2.172^{*}$ & 1.744 & $2.631 \dagger$ & $6.546^{* *}$ \\
\hline $\mathrm{ADG}^{2} \mathrm{~d} 0-29(\mathrm{~kg} / \mathrm{d})$ & 0.222 & 0.309 & 0.136 & 0.066 & 0.056 & $-0.087^{*}$ & 0.070 & $0.087 \dagger$ & $0.243 * *$ \\
\hline Withers height $^{3}(\mathrm{~cm})$ & 4.24 & 3.74 & 2.54 & 2.86 & 0.63 & 0.50 & -0.32 & $1.70 *$ & 0.88 \\
\hline Hip height $^{3}(\mathrm{~cm})$ & 4.74 & 4.23 & 2.25 & 3.42 & 0.81 & 0.51 & $-1.18]$ & $2.49^{*}$ & 0.81 \\
\hline Body length ${ }^{3}(\mathrm{~cm})$ & 4.58 & 4.28 & 2.49 & 2.65 & 1.09 & 0.30 & -0.16 & 2.10 & 1.64 \\
\hline Heart girth $^{3}(\mathrm{~cm})$ & 5.52 & 5.69 & 4.45 & 2.77 & 0.57 & -0.17 & $1.68 \dagger$ & 1.08 & $2.92 * *$ \\
\hline Total DMI (kg) & 18.466 & 18.463 & 11.415 & 10.574 & 1.234 & 0.004 & 0.841 & $7.052^{* *}$ & $7.889^{* *}$ \\
\hline Feed efficiency ${ }^{4}$ & 0.338 & 0.445 & 0.309 & 0.179 & 0.087 & $-0.107^{*}$ & $0.130 *$ & 0.029 & $0.266^{* *}$ \\
\hline
\end{tabular}

${ }^{1}$ Significance determined by slicing interaction of breed and gender.

${ }^{2} \mathrm{ADG}=$ Average daily gain.

${ }^{3}$ Gain, d 1 to 29 .

${ }^{4} \mathrm{~d} 0$ to 29 ; calculation: (kg BW gain)/(kg DMI).

$\dagger P<0.10$.

$* P<0.05$.

$* * P<0.01$

\section{Health}

Distribution of fecal scores was similar for all 4 treatments. Distribution of scores was different for breedgender groups, but biological significance of these differences was difficult to explain. Four calves died during the course of the experiment. Incidences of death and health problems were not different between treatment or breed-gender groups.

\section{CONCLUSIONS}

Calves fed an equal amount of IgG from MC or a CR attained equivalent plasma IgG concentrations at $24 \mathrm{~h}$ of age. Apparent clearance rate of passively acquired IgG was faster in calves fed MC than in calves fed CR. Calves fed MC had greater feed efficiency than calves fed CR. No other differences in growth or health perfor- mance were attributable to source of IgG in the first 24 h. However, while CR may provide adequate amounts of IgG, the viability and specificity of antibodies, as well as the ratio of $\mathrm{IgG}_{1}$ to $\mathrm{IgG}_{2}$, are potential concerns for the efficacy of these products. If IgG molecules are not viable and specific for pathogens in the local environment, then amount provided is irrelevant. Effects of intense processing required to isolate and concentrate IgG from animal proteins on activity of IgG also need to be determined. Furthermore, the ratio of $\mathrm{IgG}_{1}$ to $\mathrm{IgG}_{2}$ in colostrum is likely skewed in favor of $\mathrm{IgG}_{1}$ for a physiological reason. The impact of changing this ratio needs to be evaluated more closely. If calves receiving $\mathrm{CR}$ are stimulated to produce $\mathrm{IgG}_{1}$, then the product could be very valuable in providing enough initial $\mathrm{IgG}_{1}$ to effectively protect the calf until endogenous production begins. At the same time, $\mathrm{IgG}_{2}$ would be present

Table 8. Least square means of DMI and feed efficiency in calves fed pooled maternal colostrum (MC) or replacement $(\mathrm{R})$ and milk replacer with $(\mathrm{PL})$ or without $(\mathrm{N})$ animal plasma.

\begin{tabular}{|c|c|c|c|c|c|c|c|c|c|}
\hline \multirow[b]{3}{*}{ Variable } & \multicolumn{4}{|c|}{ Least square means } & \multirow[b]{3}{*}{$\mathrm{SE}$} & \multicolumn{4}{|c|}{ Differences of means ${ }^{1}$} \\
\hline & \multicolumn{2}{|c|}{ Colostrum } & \multicolumn{2}{|c|}{ Replacement } & & \multicolumn{2}{|c|}{$\mathrm{N}$ minus $\mathrm{PL}$} & \multicolumn{2}{|c|}{ MC minus $\mathrm{R}$} \\
\hline & $\mathrm{N}$ & PL & $\mathrm{N}$ & PL & & $\mathrm{MC}$ & $\mathrm{R}$ & $\mathrm{N}$ & $\mathrm{P}$ \\
\hline Total DMI (kg) & 15.668 & 14.996 & 13.667 & 14.586 & 1.239 & 0.671 & -0.918 & 2.000 & 0.411 \\
\hline Milk replacer DMI (kg) & 10.681 & 11.036 & 9.782 & 10.925 & 0.584 & -0.355 & -1.143 & 0.899 & 0.112 \\
\hline Starter DMI (kg) & 4.951 & 3.940 & 3.851 & 3.705 & 0.772 & 1.011 & 0.145 & 1.100 & 0.234 \\
\hline Feed efficiency ${ }^{2}$ & 0.432 & 0.357 & 0.224 & 0.258 & 0.087 & 0.075 & -0.034 & $0.208 * *$ & $0.099 \dagger$ \\
\hline
\end{tabular}

${ }^{1}$ Significance determined by slicing interaction of IgG source and milk replacer.

${ }^{2} \mathrm{~d} 0$ to 29 ; calculation: (kg BW gain)/(kg DMI).

$\dagger P<0.10$.

$* * P<0.01$ 


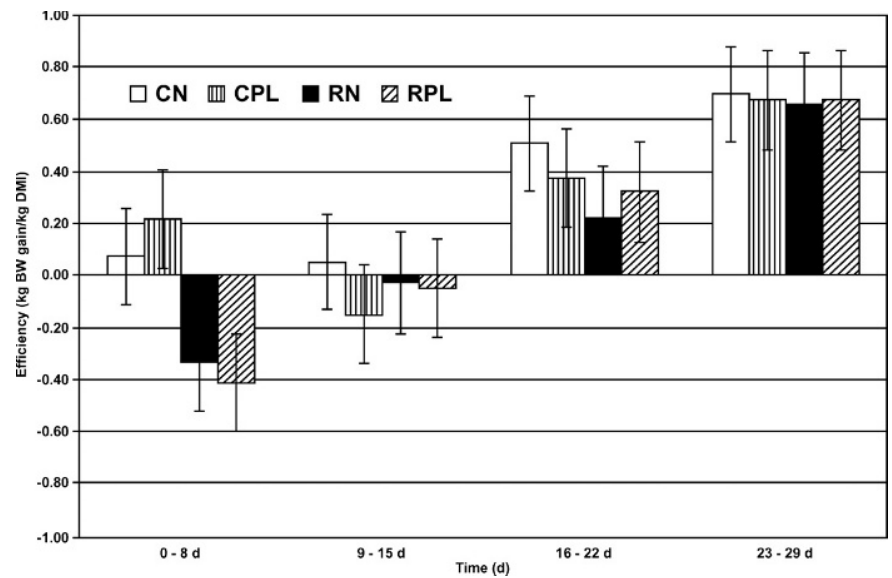

Figure 3. Feed efficiency (kg BW gain/kg DMI) by week in calves fed maternal colostrum at birth and milk replacer without animal plasma for $1 \mathrm{mo}(\mathrm{CN})$, maternal colostrum at birth and milk replacer with animal plasma for 1 mo (CPL), colostrum replacement at birth and milk replacer without animal plasma for $1 \mathrm{mo}(\mathrm{RN})$, or colostrum replacement at birth and milk replacer with animal plasma for 1 mo (RPL). Calves fed colostrum were more efficient than calves fed replacement from d 0 to 8 .

in excess of normal concentrations and may offer additional benefits. On the other hand, increased concentrations of $\operatorname{IgG}_{2}$ may inhibit $\operatorname{IgG}_{1}$ production and lead to reduced immunity as IgG is cleared from the blood. However, since no differences were observed in morbidity or mortality in this trial, it may be assumed that $\mathrm{CR}$ offered equivalent protection as $\mathrm{MC}$ under the conditions of this study.

No differences from controls were observed in the growth or health of calves fed milk replacer containing animal plasma, which indicates it is an acceptable replacement for up to $20 \%$ of milk protein in milk replacers. Further investigation is required to determine whether animal plasma provides health benefits to calves in addition to meeting nutritional requirements.

\section{ACKNOWLEDGMENTS}

The authors would like to thank Stacy Wampler, Scott Bascom, and Curtis Caldwell for their help in feeding and in caring for calves. Support for this project provided by the John Lee Pratt Foundation and APC, Inc.

\section{REFERENCES}

Arthington, J. D., M. B. Cattell, and J. D. Quigley, III. 2000a. Effect of dietary IgG source (colostrum, serum, or milk-derived supplement) on the efficiency of Ig absorption in newborn Holstein calves. J. Dairy Sci. 83:1463-1467.

Arthington, J. D., M. B. Cattell, J. D. Quigley, III, G. C. McCoy, and W. L. Hurley. 2000b. Passive immunoglobulin transfer in newborn calves fed colostrum or spray-dried serum protein alone or as a supplement to colostrum of varying quality. J. Dairy Sci. 83:2834-2838.

Besser, T. E., T. C. McGuire, C. C. Gay, and L. C. Pritchett. 1988. Transfer of functional immunoglobulin G (IgG) antibody into the gastrointestinal tract accounts for IgG clearance in calves. J. Virol. 62:2234-2237.

Butler, J. E. 1983. Bovine immunoglobulins: An augmented review. Vet. Immunol. Immunopathol. 4:43-152.

Chaney, A. L., and E. P. Marbach. 1962. Modified reagents for determination of urea and ammonia. Clin. Chem. 8:130-132.

Davenport, D. F., J. D. Quigley III, J. E. Martin, J. A. Holt, and J. D. Arthington. 2000. Addition of casein or whey protein to colostrum or a colostrum supplement product on absorption of IgG in neonatal calves. J. Dairy Sci. 83:2813-2819.

Davis, C. L., and J. K. Drackley. 1998. The Development, Nutrition, and Management of the Young Calf. 1st ed. Iowa State University Press, Ames.

Devery, J. E., C. L. Davis, and B. L. Larson. 1979. Endogenous production of immunoglobulin IgG1 in newborn calves. J. Dairy Sci. 62:1814-1818.

Drew, M. D. 1994. Effects of immunoglobulin fortification of milk replacers on the performance of calves challenged with Escherichia coli. J. Dairy Sci. 77(Suppl. 1):298. (Abstr.)

Duarte, R. T., M. C. Carvalho Simões, and V. C. Sgarbieri. 1999. Bovine blood components: fractionation, composition, and nutritive value. J. Agric. Food Chem. 47:231-236.

Etzel, L. R., R. E. Strohbehn, and J. K. McVicker. 1997. Development of an automated turbidimetric immunoassay for quantification of bovine serum immunoglobulin G. Am. J. Vet. Res. 58:1201-1205.

Foley, J. A., and D. E. Otterby. 1978. Availability, storage, treatment, composition, and feeding value of surplus colostrum: a review. J. Dairy Sci. 61:1033-1060.

Garry, F. B., R. Adams, M. B. Cattell, and R. P. Dinsmore. 1996. Comparison of passive immunoglobulin transfer to dairy calves fed colostrum or commercially available colostral-supplement products. JAVMA 208:107-110.

Lammers, B. P., A. J. Heinrichs, and A. Aydin. 1998. The effect of whey protein concentrate or dried skim milk in milk replacer on calf performance and blood metabolites. J. Dairy Sci. 81:19401945.

Littell, R. C., G. A. Milliken, W. W. Stroup, and R. D. Wolfinger. 1996. SAS System for Mixed Models. 1st ed. SAS Inst., Inc., Cary, NC.

Logan, E. F., D. G. McBeath, and B. G. Lowman. 1974. Quantitative studies on serum immunoglobulin levels in suckled calves from birth to five weeks. Vet. Rec. 94:367-370.

Mayer, B., A. Zolnai, L. V. Frenyó, V. Jancsik, Z. Szentirmay, L. Hammarstrom, and I. Kacskovics. 2002. Redistribution of the sheep neonatal Fc receptor in the mammary gland around the time of parturition in ewes and its localization in the small intestine of neonatal lambs. Immunology 107:288-296.

Mee, J. F., K. J. O'Farrell, P. Reitsma, and R. Mehra. 1996. Effect of a whey protein concentrate used as a colostrum substitute or supplement on calf immunity, weight gain, and health. J. Dairy Sci. 79:886-894.

Morrill, J. L., J. M. Morrill, A. M. Feyerherm, and J. F. Laster. 1995. Plasma proteins and a probiotic as ingredients in milk replacer. J. Dairy Sci. 75:902-907.

NAHMS. 1993. Dairy herd management practices focusing on preweaned heifers. USDA: APHIS:VS, Fort Collins, CO.

Quigley, J. D. III, and J. K. Bernard. 1996. Milk replacers with or without animal plasma for dairy calves. J. Dairy Sci. 79:18811884.

Quigley, J. D. III, J. J. Drewry, and K. R. Martin. 1998a. Estimation of plasma volume in Holstein and Jersey calves. J. Dairy Sci. 81:1308-1312.

Quigley, J. D. III, D. L. Fike, M. N. Egerton, J. J. Drewry, and J. D. Arthington. 1998b. Effects of a colostrum replacement product derived from serum on immunoglobulin $\mathrm{G}$ absorption by calves. J. Dairy Sci. 81:1936-1939. 
Quigley, J. D. III, P. French, and R. E. James. 2000a. Effect of pH on absorption of immunoglobulin $\mathrm{G}$ in neonatal calves. J. Dairy Sci. 83:1853-1855.

Quigley, J. D. III, C. A. Jaynes, M. L. Miller, E. Schanus, H. ChesterJones, G. D. Marx, and D. M. Allen. 2000b. Effects of hydrolyzed spray dried red blood cells in milk replacer on calf intake, body weight gain, and efficiency. J. Dairy Sci. 83:788-794.

Quigley, J. D. III, C. J. Kost, and T. M. Wolfe. 2002. Absorption of protein and IgG in calves fed a colostrum supplement or replacer. J. Dairy Sci. 85:1243-1248.

Quigley, J. D., R. E. Strohbehn, C. J. Kost, and M. M. O'Brien. 2001. Formulation of colostrum supplements, colostrum replacers and acquisition of passive immunity in neonatal calves. J. Dairy Sci. 84:2059-2065.

Smith, P. K., R. I. Krohn, G. T. Hermanson, A. K. Mallia, F. H. Gartner, M. D. Provenzano, E. K. Fujimmoto, N. M. Goeke, B. J. Olson, and D. G. Klenk. 1985. Measurement of protein using bicinchoninic acid. Anal. Biochem. 150:76-85.
Stabel, J. R. 2001. On-farm batch pasteurization destroys Mycobacterium paratuberculosis in waste milk. J. Dairy Sci. 84:524-527.

Stott, G. H., and A. Fellah. 1983. Colostral immunoglobulin absorption linearly related to concentration for calves. J. Dairy Sci. 66:1319-1328.

Stott, G. H., D. B. Marx, B. E. Menefee, and G. T. Nightengale. 1979. Colostral immunoglobulin transfer in calves I. period of absorption. J. Dairy Sci. 62:1632-1638.

Todd, A. G., P. B. D. Whyte, and P. D. Carroll. 1993. A comparison of serum immunoglobulin concentrations in neo-natal calves fed substitute colostrums. Aust. Vet. J. 70:154-155.

Weatherburn, M. W. 1967. Phenol-hypochlorite reaction for determination of ammonia. Anal. Chem. 39:971-974.

Wells, S. J., D. A. Dargatz, and S. L. Ott. 1996. Factors associated with mortality to 21 days of life in dairy heifers in the United States. Prevent. Vet. Med. 29:9-19.

Zaremba, W., W. M. Guterbock, and C. A. Holmberg. 1993. Efficacy of a dried colostrum powder in the prevention of disease in neonatal Holstein calves. J. Dairy Sci. 76:831-836. 